Revue bibliographique pour le domaine irano-aryen

\title{
Esmaeil Haddadian-Moghaddam. Literary Translation in Modern Iran: A Sociological Study
}

\section{Laetitia Nanquette}

\section{Q OpenEdition \\ 1 Journals}

\section{Electronic version}

URL: http://journals.openedition.org/abstractairanica/46050

DOI: $10.4000 /$ abstractairanica.46050

ISBN: 1961-960X

ISSN: 1961-960X

Publisher:

CNRS (UMR 7528 Mondes iraniens et indiens), Éditions de l'IFRI

\section{Electronic reference}

Laetitia Nanquette, «Esmaeil Haddadian-Moghaddam. Literary Translation in Modern Iran: A Sociological Study », Abstracta Iranica [Online], Volume 37-38-39 | 2018, document 5, Online since 30 December 2018, connection on 26 September 2020. URL : http://journals.openedition.org/abstractairanica/ 46050 ; DOI : https://doi.org/10.4000/abstractairanica.46050

This text was automatically generated on 26 September 2020

Tous droits réservés 


\title{
Esmaeil Haddadian-Moghaddam. Literary Translation in Modern Iran: A Sociological Study
}

\author{
Laetitia Nanquette
}

\section{REFERENCES}

Esmaeil Haddadian-Moghaddam. Literary Translation in Modern Iran: A Sociological Study.

Amsterdam: John Benjamins, 2014, xix+236 p.

1 This study is a groundbreaking analysis of the field of literary translation in Iran from the end of the $19^{\text {th }}$ century until today. Based on a Bourdieusian sociology of culture, it analyses how translation processes work and how translation is practiced, from the selection of texts to the translation process. It focuses on novels from English. As it is based on a PhD thesis, the first two chapters are devoted to methodological and historical issues. From chapter 3, the author studies translation during different periods: the Qajar; the Pahlavi; and after the 1979 Revolution. The author wanted to offer a comprehensive view of the field and therefore, in some places, the analysis could have been more developed, but the mixture of textual analyses, interviews with agents of translation (translators, publishers, editors), and case studies of cultural institutions makes it an essential resource for anyone interested in modern and contemporary Iranian literature, because of the central role that translated texts play in the Iranian literary field. 


\section{AUTHORS}

\section{LAETITIA NANQUETTE}

University of New South Wales, Sydney 